\title{
IGCP 596, Mid-Paleozoic climate and biodiversity: Proceedings of the Opening Meeting in Graz, Austria (September 19-24, 2011)
}

\author{
Editorial preface by Erika Kido, Thomas J. Suttner, Peter Königshof \& \\ Johnny A. Waters
}

IGCP 596 (International Geoscience Programme, UNESCO; duration: 2011-2015) focuses on climate change and biodiversity patterns in the Mid-Palaeozoic. The Mid-Palaeozoic was a time of dynamic long-term climate change accompanied by substantial variations in biodiversity. During this project, we intend to increase the record of biodiversity, revise and update the Paleobiology database and clarify links between specific biodiversity patterns and climate change based on the application of additional methods for palaeoclimate modeling such as geochemistry and geophysics (in collaboration with IGCP 580). Currently, the global network of IGCP 596 consists of 135 scientists from 26 countries.

The Opening Meeting of IGCP 596 was organized in Graz from $19^{\text {th }}$ to $24^{\text {th }}$ of September 2011 (Fig. 1A). The general programme consisted of an indoor scientific session, which was followed by a field-workshop in the Carnic Alps (Austria-Italy). 36 delegates (among them 15 women in science and $5 \mathrm{PhD}$ students) from 13 countries attended the initial meeting (Fig. 1B): Austria (6), Belgium (6), Bulgaria (1), Czech Republic (3), France (1), Germany (2), Japan (3), Mongolia (2), Poland (1), Russia (5), Spain (2), Turkey (2), and USA (2). A group of 18 participants joined the field workshop and visited the pre-Variscan sequences of the Carnic Alps (Fig. 1C).

The scientific session was divided into the four primary topics of interest to IGCP 596. Each topic was opened with a special keynote lecture given by an expert in the field:

1) Biodiversity patterns and evolution of fossils

Keynote presented by Yarinpil Ariuchimeg (Mongolia) on Carboniferous fossils of Mongolia.

2) Climate perturbations: Effect on marine organisms

Keynote presented by Michael Joachimski (Germany) on climate and ice volume history of the Mid-Palaeozoic: Insights from oxygen isotope proxies.

3) Multidisciplinary approach: Geochemistry and Geophysics

Keynote presented by Anne-Christine da Silva (Belgium) on magnetic susceptibility evolution on Palaeozoic sedimentary settings, a clue for past palaeoenvironments.

4) Mid-Palaeozoic bio- and lithostratigraphy

Keynote presented by Nadezhda G. Izokh (Russia) on biodiversity of Devonian conodonts from the West Siberia.

More details on keynote lectures and other presentations are provided in the conference abstract volume which is available online at http://erdwissenschaften.uni-graz.at/publikationen/zeitschrift/band16/index_de.php

The scientific part of the meeting was followed by a field workshop to Devonian and Carboniferous outcrops in the Carnic Alps. For the first day 3 stops were scheduled: the show-mine "Terra Montana", the Geopark-Center in Dellach and the famous Ordovician to Devonian section in the Cellon Avalanche gully near the Plöcken Pass at the Austro-Italian border. On the second day we moved from the Valentinalm to Lake Wolayer (Fig. 1D). On both sides of the mountain-path, which is part of the Carnic Alps Geotrail, different depositional environments of pre-Variscan units are exposed. At the end of a long day full of discussions on biodiversity patterns of marine fossil groups present in Devonian deposits of this area, an evening talk on life and achievements of Otto H. Walliser was given by Hans Peter Schönlaub. On the third day we observed fossiliferous deposits of the Devonian shallow marine carbonates of Mount Seewarte on the way down to the village of Collina (Friuli, Italy) from where we returned to Graz.

We would like to thank all delegates for attending the IGCP 596 Opening Meeting and hope that the spirit of this conference will retain the enthusiasm of Devonian and Carboniferous workers in sharing their knowledge and experience with colleagues all over the world. 

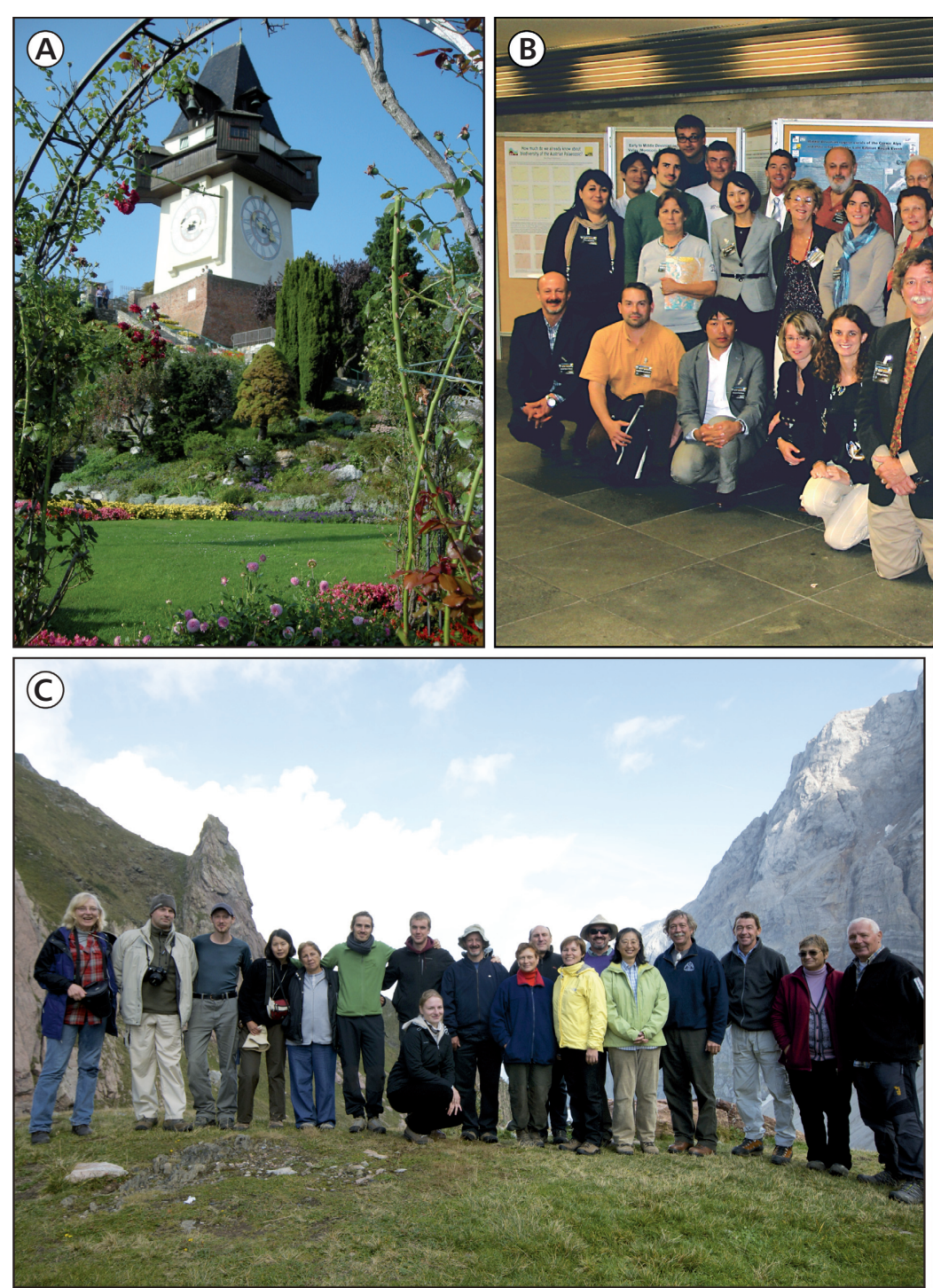

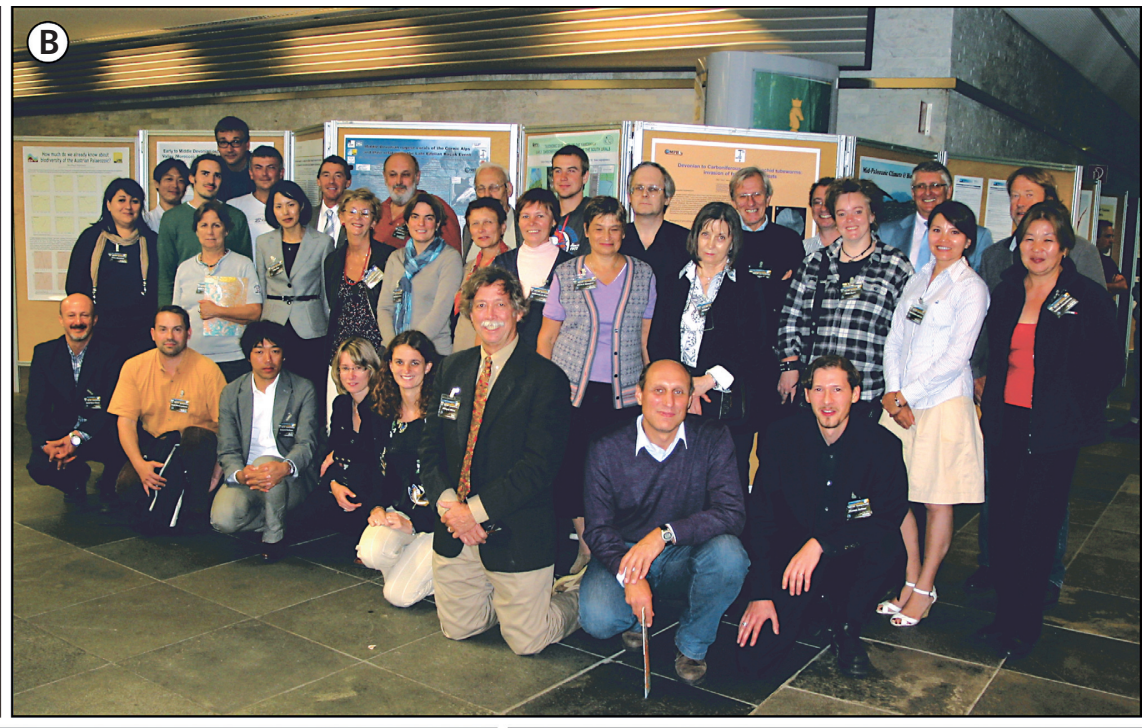

(D)

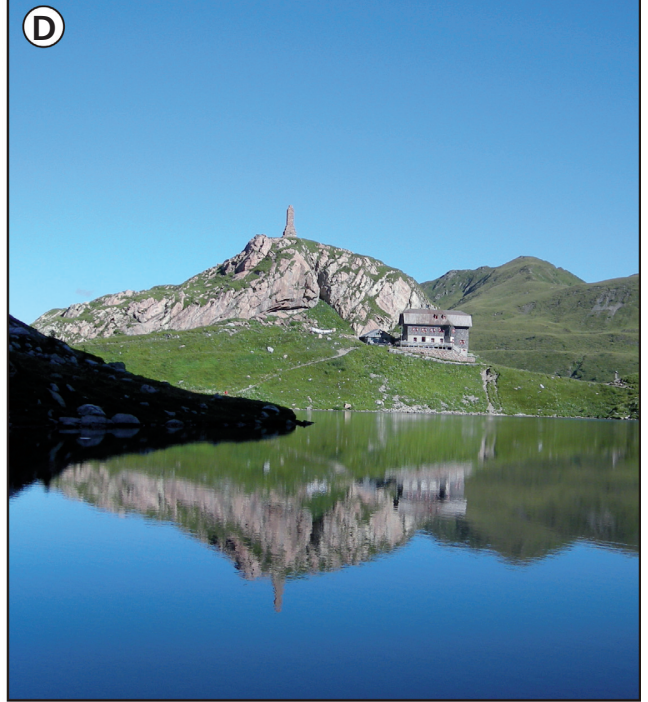

Figure 1. A - the clock tower of Graz, landmark of the town in the city centre (photo by Erika Kido). $\bullet \mathrm{B}-$ participants of the scientific session held in the University of Graz (photo by Erwin Kober). $\bullet \mathrm{C}$ - participants of the field workshop run in the Carnic Alps (photo by Barbara Waters). $\bullet$ D - Mountain Hut at Lake Wolayer (photo by Thomas Suttner).

One result of this conference is this proceedings volume with a collection of 9 manuscripts concerning the Devonian and Carboniferous periods. Another paper dealing with Carboniferous epiphytic plants counts as a contribution to IGCP 575 (The Pennsylvanian terrestrial habitats and biotas of southeastern Euramerica). Because IGCP 596 shares the aim to increase and refine the documentation of biodiversity during the Palaeozoic with the closely related project IGCP 591 (The Early to Middle Paleozoic Revolution: Bridging the gap between the Great Ordovician biodiversification event and the Devonian terrestrial revolution), additional three articles dealing with the Ordovician to Silurian time interval are included in this issue as contribution to the IGCP 591. In summary, the collection of 13 papers published in this issue of the Bulletin of Geosciences combine various topics related to geochemistry, palynology, ichnology and taxonomy (radiolarians, foraminifers, ostracods, bivalves and conodonts), having a strong focus on biostratigraphy, palaeoecology and the interpretation of palaeoenvironmental conditions.

The first contribution by Manchuk et al. (2013) concerns biostratigraphic ranges of late Silurian to early Devonian radiolarians paired with U-Pb SHRIMP data of magmatic zircons from tuffaceous rocks of the Fukuji area in Japan which allow an age-refinement of some radiolarian biozones. The manuscript shows that this technique might lead to a more precise radiolarian biostratigraphy, if applied in other radiolarian-bearing sequences globally.

Casier et al. (2013) provide a detailed study on the palaeoenvironmental development across the Givetian to Frasnian transition from the Dinant Synclinorium in Belgium which is based on ostracod-taxonomy and the analysis of rock facies. 
Only 12 of 56 ostracod species survived the Frasnes Event in the sampled section, which is related to changing environmental conditions caused by a rapid sea-level rise.

The taxonomic study on foraminifers of the Devonian-Carboniferous boundary interval in the South Urals by Kulagina (2013) shows that biodiversity especially of endothyrids reached a peak during the Late Devonian which was followed by a drop in evolutionary rates and extinction related to the Hangenberg Event. Lowest diversity dominated by unilocular growth forms is observed in the early Tournaisian.

Other two contributions from localities in the southern Urals provide new data on Early and Late Devonian conodont assemblages. Mavrinskaya \& Slavík (2013) investigated Lochkovian-Pragian conodonts of the West Zilair Zone. They provide distribution patterns of conodont genera, which indicate that conodont diversity declined during the late Lochkovian pesavis Zone. Tagarieva (2013) documents a significant change in the conodont assemblage across the Frasnian-Famennian interval of the West Uralian Folded Zone which is reflected by a replacement of a late Frasnian diverse palmatolepid biofacies by an early Famennian icriodontid biofacies that is very low in diversity.

Further papers on biostratigraphy deal with Middle to Late Devonian conodonts from the Spanish Central Pyrenees (Gouwy et al. 2013, Liao \& Valenzuela-Ríos 2013) and with Late Devonian conodont faunas from the Shotori Range in Iran (Bahrami et al. 2013). Based on a high-resolution sampling and a detailed systematic study, authors increase and consolidate knowledge on conodont biostratigraphy, which is an important contribution to the understanding of the phylogenetic relationship of conodont taxa.

The last publication related to the Devonian is given by Mikuláš et al. (2013). The authors provide a detailed systematic study of ichnofossils from Upper Givetian to Middle Frasnian deposits of the East European Platform in NW Russia. They document a diverse ichnoassemblage which together with sedimentological data allow conclusive interpretations on the palaeoenvironment.

The paper contributed by Pšenička \& Opluštil (2013) concerns epiphytic plants from middle Moscovian ash-fall deposits of Radnice Basin in the Czech Republic. A detailed study of the well preserved plant remains concludes that two types of possible epiphytic Selaginella-like plants grew in the leafy distal parts of the tree-top branches of arborescent lycopsids and on trunks of the arborescent gymnosperm Cordaites borassifolius or the lycopsid Lepidodendron (Paralycopodites) simile. Hence the identification of epiphytes in the fossil record is problematic the herein presented conclusions are based on many indirect evidences and considerations by the authors.

Jiménez-Sánchez et al. (2013) undertook statistical analyses of the morphological differences between congeneric species of Late Ordovician bryozoans from warm-water settings (Avalonia, Baltic, and Laurentia-Siberian provinces) and cold-water setting (Mediterranean province) in order to test palaeogeographical patterns in Late Ordovician bryozoan morphology. Their result shows that the morphology in some individual genera of Ordovician bryozoans is useful as proxy for temperature-related patterns.

A detailed taxonomic study of the Middle Ordovician bivalves from Prague Basin (Czech Republic) is provided by Polechová (2013). The author describes a diversified bivalve fauna consisting of twelve species in nine genera indicating the palaeoecological aspect of each species. The fauna shows close affinities to bivalves, which occur in coeval deposits of Spain and France. Additionally the palaeogeographic distribution of the fauna is discussed.

Frýda \& Manda (2013) provide an uninterrupted and complete stable carbon isotope record from the mid-Ludfordian (late Silurian) sequence in Barrandian area in Czech Republic. The authors compare the $\delta^{13} \mathrm{C}$ chemostratigraphic zonation with graptolite and conodont biostratigraphic zonations and propose an integrated $\delta^{13} \mathrm{C}$, graptolite and conodont stratigraphy for the mid-Ludfordian. The study is an important contribution for better understanding of the geochemical event in the mid-Ludfordian.

\section{Acknowledgements}

Five delegates to the conference were supported by grants from the UNESCO/IUGS. One of the keynote speakers, Nadezhda G. Izokh, was invited within the framework of the "NAWI GRAZ LECTURE", a joint project of the University of Graz and the Graz University of Technology. Other two keynote speakers and one student were supported by grants from the Austrian Science Fund (project FWF P23775-B17) and NAP0017 (subproject of IGCP 580). The organizers would like to express their sincere thanks to all institutions acknowledged here for financial support.

Furthermore, we are grateful to Jiří Frýda for his offer to publish the proceedings of the first conference of IGCP 596 in the Bulletin of Geosciences. The responsible editors, Jindřich Hladil, Štěpán Manda, Ladislav Slavík and Petr Štorch, and Šárka Doležalová are kindly thanked for their excellent work on the layout and in handling the review process for each of the submitted manuscripts. Finally we would like to acknowledge all colleagues that helped to improve the manuscripts with constructive reviews. Manuscripts included in this volume represent contributions to IGCP 596, IGCP 591 and IGCP 575. 


\section{References}

Bahrami, A., Corradini, C., Over, D.J. \& YAzdi, M. 2013. Conodont biostratigraphy of the upper Frasnian-lower Famennian transitional deposits in the Shotori Range, Tabas area, Central-East Iran Microplate. Bulletin of Geosciences 88(2), 369-388. DOI 10.3140/bull.geosci.1353

Casier, J.-G., Devleeschoumer, X., Maillet, S., Petitclerc, E. \& Préat, A. 2013. Ostracods and rock facies across the Givetian/Frasnian boundary interval in the Sourd d'Ave section at Ave-et-Auffe (Dinant Synclinorium, Ardenne, Belgium). Bulletin of Geosciences 88(2), 241-264. DOI 10.3140/bull.geosci.1340

FRÝDA, J. \& MANDA, Š. 2013. A long-lasting steady period of isotopically heavy carbon in the late Silurian ocean: evolution of the $\delta^{13} \mathrm{C}$ record and its significance for an integrated $\delta^{13} \mathrm{C}$, graptolite and conodont stratigraphy. Bulletin of Geosciences 88(2), 463-482. DOI 10.3140/bull.geosci.1436

Gouwy, S., Liao, J.-C. \& Valenzuela-Ríos, J.I. 2013. Eifelian (Middle Devonian) to Lower Frasnian (Upper Devonian) conodont biostratigraphy in the Villech section (Spanish Central Pyrenees). Bulletin of Geosciences 88(2), 315-338. DOI 10.3140/bull.geosci.1341

JimÉNEZ-SÁncheZ, A., TAYloR, P.D. \& GómeZ, J.B. 2013. Palaeogeographical patterns in Late Ordovician bryozoan morphology as proxies for temperature. Bulletin of Geosciences 88(2), 417-426. DOI 10.3140/bull.geosci.1396

Kulagina, E.I. 2013. Taxonomic diversity of foraminifers of the Devonian-Carboniferous boundary interval in the South Urals. Bulletin of Geosciences 88(2), 265-282. DOI 10.3140/bull.geosci.1347

Liao, J.-C. \& Valenzuela-Ríos, J.I. 2013. The Middle and Upper Devonian conodont sequence from La Guardia D’Àres Sections (Spanish Central Pyrenees). Bulletin of Geosciences 88(2), 339-368. DOI 10.3140/bull.geosci.1348

ManchuK, N., Horie, K. \& TsukAdA, K. 2013. SHRIMP U-Pb age of the radiolarian-bearing Yoshiki Formation in Japan. Bulletin of Geosciences 88(2), 223-240. DOI 10.3140/bull.geosci.1342

Mavrinskaya, T. \& Slavík, L. 2013. Correlation of Early Devonian (Lochkovian-early Pragian) conodont faunas of the South Urals (Russia). Bulletin of Geosciences 88(2), 283-296. DOI 10.3140/bull.geosci.1404

Mikuláš, R., Mešḳis, S., Ivanov, A., Lukševičs, E., Zupin̦š, I. \& Stinkulis, Ģ. 2013. A rich ichnofossil assemblage from the Frasnian (Upper Devonian) deposits at Andoma Hill, Onega Lake, Russia. Bulletin of Geosciences 88(2), 389-400. DOI 10.3140/bull.geosci.1358

PolechovÁ, M. 2013. Bivalves from the Middle Ordovician Šárka Formation (Prague Basin, Czech Republic). Bulletin of Geosciences $88(2)$, 427-461. DOI 10.3140/bull.geosci.1426

PŠENIČKA, J. \& OpluštiL, S. 2013. The epiphytic plants in the fossil record and its example from in situ tuff from Pennsylvanian of Radnice Basin (Czech Republic). Bulletin of Geosciences 88(2), 401-416. DOI 10.3140/bull.geosci.1376

TAgarieva, R.C. 2013. Conodont biodiversity of the Frasnian-Famennian boundary interval (Upper Devonian) in the Southern Urals. Bulletin of Geosciences 88(2), 297-314. DOI 10.3140/bull.geosci.1344 